\title{
A New Approach to Zakat Management For Unprecedented Times
}

\author{
Azim Kidwai \\ National Zakat Foundation Worldwide \\ Mohamed El Mehdi Zidani \\ United Nations High Commissioner for Refugees (UNHCR)
}

\begin{abstract}
This article stresses the necessity of Zakat playing a primary role in response to humanitarian crises in the Muslim world and beyond. This will not be possible without a rethinking of the original spirit of Zakat as found in the scriptures, in addition to the adoption of innovative tools in Zakat management. As an increasing number of multilateral organizations are today being involved with Islamic philanthropy in general and Zakat in particular, an important topic in this discussion is about partnerships between these organizations and traditional faith-based Zakat houses and collectors. The approach suggested in this paper is a collaborative approach by which faith-based institutions would ensure the spirit of Zakat - which remains in its essence an act of faith - is preserved, while having the highest possible impact on the maximum of people in need by benefiting from the distribution networks, efficiency and other best practices of multi-lateral organizations.
\end{abstract}

Keywords: Zakat, Partnership, Humanitarian impact, Innovation

\section{INTRODUCTION}

"Today over 70 million people have beenforcibly displaced around the world. $60 \%$ of these populations come from OIC countries. "2

This is a disturbing statement, and from a leading figure in global and Islamic philanthropy, one that forces us to take note. Unfortunately, the refugee situation is one among many other humanitarian crises mostly affecting OIC countries. In fact, " $42 \%$ of Sovereign Muslim nations today find themselves dependent on others" 3 , needing humanitarian assistance and dependent on aid. The reasons for this are complex and beyond the scope of this

\footnotetext{
${ }^{2}$ Quote from Khaled Khalifa, Regional Representative to the Gulf Council Countries \& Senior Advisor on Islamic finance, UNHCR,
}

paper, however, it would be fair to say that it is incumbent upon the major donors and significant recipients to reflect on and reconsider how the issue is challenged today. We cannot accept that the world generates ever more enormous wealth and at the same time ever greater poverty.

There must be a much more strategic look at building capacity from within communities. International aid cannot be the only answer for some of the critical challenges facing needy people across much of the Muslim world. The question is: can there be a solution that builds equity and capacity in countries currently facing economic

during the International Shariah Scholars Forum 2019.

${ }^{3}$ Quote by Sikander Khan, Director of the UNICEF, during the World Zakat Forum 2019. 
dependency and a persistent need for humanitarian assistance?

In September 2019, at the Sustainable Development Goals (SDG) Business Forum at the SDG Summit, the United Nations Secretary-General highlighted how a persistent $\$ 2.5$ trillion annual financing gap stands in the way of the SDGs (UN Deputy SecretaryGeneral, 2019). This astonishing gap will not simply be filled by more significant commitments from the major donors, who have their own challenges. Changes in the role played by some leading nations in international assistance, as well as the Corona pandemic, has currently rocked the global economy. How realistically can these gaps be bridged? The reality is that there is no single answer for this: a multifaceted approach is required.

\section{THE SPIRIT OF ZAKAT}

The potential size of the annual Zakat pool has been estimated between US\$200 billion and US\$1 trillion, according to Obaidullah and Shirazi in 2015 and the World Bank and IDBG in 2016 (Rehman \& Pickup, 2018). This makes obvious the fact that Zakat should be considered as a key topic in this debate. Its role is easily understood by how closely UN SDGs are linked to priorities within the Zakat management framework, with SDGs such as no poverty (SDG 1), zero hunger (SDG 2), reduced inequalities (SDG 10) all being at the heart of a successful Zakat management approach.

In Arabic, Zakat means growth, blessings, purification and development. It requires Muslims to pay $2.5 \%$ of their qualifying wealth on an annual basis. Zakat provides an opportunity for the payer to fulfil their duty to God by almsgiving. It also provides an opportunity to help the poor. However, the concept of Zakat goes beyond this, which is why there needs to be a review of how Zakat managers consider Zakat management. Unfortunately, in many countries Zakat is managed with only a concern for absolute poverty relief, rather than social empowerment of the whole community. The very soul of Zakat is in moving people from dependence to independence, and from being mentally and financially constrained to being intellectually and socially emancipated. This is most clearly seen from the constitutional verse for Zakat in the Quran, in which God All Mighty provides a very clear direction on the macro approach to alms, giving that $\mathrm{He}$ is instructing to distinguish Zakat from general charitable giving in the form of Sadaqah.

In the Quran, Allah says there are eight recipients of Zakat:

"Indeed, Zakat expenditures are only for [1] the poor and [2] the needy, [3] those who work on [administering] it and [4] for bringing hearts together, [5] to [free] those in bondage and [6] for those in debt, [7] for the cause of Allah and [8] for the stranded traveller. [This is] an obligation from Allah. Allah is All-knowing, All-Wise." (Quran 9:60).

The divine instruction then is one that identifies eight clear and distinct recipient classes. We understand from this that a wider benefit will emerge if the collection and distribution are managed as per scripture. This means that, should Zakat agencies genuinely seek to build Zakat systems in line with scripture, there will be an additional blessed outcome of honour, dignity, and community spirit to transpire. Muslims 
would understand the term 'barakah', which can be understood as 'the whole is greater than the sum of its parts', but the key point here is that so much more can be achieved if a societal approach is taken to genuinely uplift the community.

Today Zakat is too often synonymous with charity and charitable funds. In reality, it could be no further from the truth. Zakat is a means of liberating man from the pursuit of wealth and consumerism. For the Zakat payer, it is genuinely intended to 'clean' one's wealth, by surrendering a small proportion to God All Mighty. Reinforcing the relationship between a human being and his/ her creator. Reminding the individual that all they have is from God, The Sustainer, and it is upon them to return some to him. And with that return there is a natural means to liberate the impoverished and dependent. There is a mechanism for hope and optimism that whatever their circumstances, God has created a social finance structure for society to give those in need a hand up, not just a 'hand out'. Taking such a perspective can completely change the way Zakat is both collected and distributed, but furthermore through whom and how it is distributed.

Zakat management bodies must recognise that the world is a very different place in 2020 than the year they were probably constituted. This is the year where some challenger banks have enabled automatic Zakat deductions from our accounts and the year blockchain has entered the realm of tracking Zakat from payer to beneficiary. In this context, it is crucial that all Zakat managers ask two tough questions:

1. Does scripture have a position in our approach to Zakat management?
2. Do efficiency and effectiveness have a guiding role in distribution?

\section{THE ROLE OF SCRIPTURE}

Zakat managers need to recognise that it is upon scripture that Zakat funds are procured. Therefore, there should be a regular review of the demands of scripture in the fast-moving world of today. We must recognise that scripturally Zakat's goal is to strengthen spiritually through economic empowerment of Muslim communities. This is an important distinction, and if Zakat was only about poverty and the poor, why would there be a separation between voluntary charity and obligatory Zakat? There is a distinction of strategic significance and this needs to be understood. The categories to which Zakat can legally be deployed are not stated by chance but are based on a divine instruction to lift the vulnerable from a state of weakness, so that they can themselves contribute to a more prosperous and pluralistic society. When man is freed from the material troubles of the world, he can find the headspace to enjoy life with a divine connection, a life of service and exemplary civil society.

Some contemporary Islamic scholars argue that Zakat entitlement and worthiness is focused on the adjective and attribute coined by Allah for the meta-categories and not just the physical recipients. This explains why Umar ibn Al Khattab, the second Caliph of Islam, did not deploy Zakat funds in one category for example, considering that it was no more relevant at his time. Each meta-category is anchored on an underlying outcome and impact which is the objective of that meta-category. Therefore, the fundamental purpose of 
Zakat can only truly be realized through the effective and empowerment focused distribution of Zakat across the eight divinely ordained categories. It cannot be a technical exercise of juristic compliance focusing on the accurate individual payment of Zakat alone, as it may fulfil the letter but then lose the soul.

Unfortunately, in many Muslim majority countries today this perspective has become a challenge. Ministerial boundaries and bureaucracies often put departments in conflict with how Zakat intersects with society. However, much more can be achieved through a more holistic approach. The empowerment of the most vulnerable in society can raise nations at an unprecedented rate. Scandinavian nations are often celebrated for their performance on social indices, but their results are not by chance, they are underpinned by a genuine welfare state and a commitment to invest at a state level in society. As such the vulnerable and needy become an ever-smaller proportion of society and at the very least the Faqeer (who have nothing) migrates to Miskeen (who has not enough) status. Utilising scriptures as such brings two major benefits:

\section{Spiritual Motivation}

Zakat is the jewel of the crown of Islamic social finance. It motivates the payer from the perspective of fulfilling a covenant with God All Mighty. At the same time, it empowers the claimant and allows them to feel social security at the hands of the society around them. It helps erode jealousy and depression with a positive attitude toward a divine approach to an equitable distribution of wealth.

\section{Economic Empowerment}

Through utilising the eight categories of distribution, a wide and diverse approach is taken to the redistribution of wealth. These categories allow the urgent needs of the poor and vulnerable to be addressed, while looking at the wider structural challenges which may have put them in this difficult situation such as debt, forced displacement and even modern-day slavery, all of which are affecting refugees. In the way we live today this is critical, regardless if one is living in a majority Muslim country or where a Muslim community is living as a minority.

A highly reflective approach
upon scripture can genuinely
revolutionise the way people in need (be
that material or spiritual), regardless if
they are in Saudi Arabia or Switzerland,
can achieve a dignified life.

Taking such a pragmatic view to scripture represents a challenge, but one with enormous rewards. Ultimately, we need to ponder: why is it that we are spending billions in Zakat funds, yet the poor are simply increasing in number and need? There must be a change and there must be a great review upon the structures through which we operate.

\section{THE PURSUIT OF EFFICIENCY \& EFFECTIVENESS}

"Verily, Allah enjoins justice, and excellence and giving help to relatives, and He forbids immoral sins, evil and tyranny. He admonishes you, so that perhaps you may take heed" (Quran, 16:90).

Excellence and its pursuit as such must be at the heart of Zakat organisations. We must be pioneering and exploring all the best and latest ways to achieve our 
goals. Zakat management bodies would highly benefit from taking the risk of implementing innovative tools. This is necessary to create a healthy environment for Zakat to flourish and respond to the unprecedented challenges of the day.

Important new and more efficient ways to manage the needs of those eligible to receive Zakat must be explored and supported. The needs of today and seemingly tomorrow oblige us to investigate better ways to manage Zakat funds, with efficiency and effectiveness sought with every dollar collected and distributed.

\section{MUTUAL BENEFIT OF THE PARTNERSHIP MODEL: UNHCR CASE STUDY}

Considering case studies like this is important as it allows us to clearly see that non-faith led organisations have a role to play. Their ability to innovate and efficiently deliver aid to those that need it, especially in hard-to-reach areas, should be embraced, given the appropriate safeguards are in place. While collection and payment of Zakat are an act of faith, it's best led firstly by agencies that are able to affirm the faith and build structures to ensure Zakat funds are managed with due regard. However, there is undoubtedly a role for organizations from outside the faith context to work with collectors to help achieve shared outcomes. Zakat collectors have the potential to embrace multilateral players that are pioneering innovative poverty alleviation programmes. When this is done with a sound social welfare strategy founded upon scripture, this could help enhance impact, reduce cost and improve reach. The key point here is to recognize this opportunity that, if embraced, could really help improve the global impact and footprint of Zakat, and wouldn't alienate refugees and host community members alike, many of whom are eligible to receive it, in their share of Zakat. Faith-based organizations should lead the way while capitalizing on strategic and sustainable partnerships with multi-lateral organizations based on an effective and impact-oriented approach. For example, taking a societal approach to respond to the immediate needs of the most vulnerable refugees and internally displaced persons (IDPs), could also build a sense of solidarity with their host Muslim brothers and sisters, implied by the dedication of a portion of Zakat to them. At the same time, for payers, it would allow them to see, feel and experience the value of effective Zakat collection, distribution and empowerment.

It is incumbent upon all key actors to actively better understand not just the role they can play, but the role they should play and their collective responsibility towards an increasing number of displaced persons globally, especially in hard-to-reach areas such as Yemen, Syria, Afghanistan, Somalia, and Mali. The mutual goodwill for cooperation and partnership on pilot and long-term basis is recommended as the best way forward to fill any gaps that might deprive millions of eligible vulnerable families from living in dignity and realizing their full potential. An additional point to consider for this approach, is the potential role local and regional faith-based humanitarian organizations can play as implementing partners in the process of assessment and monitoring the distribution of Zakat. It can widen their networks, strengthen their capacities and amplify their impact. In return, multi-lateral organizations can benefit from the local outreach of implementing partners, as well as local 
knowledge of the beneficiary population. A local approach to the collection, distribution and empowerment through Zakat can truly revolutionize the response to some of the major challenges of the world. Some of the most challenged nations have major pockets of unlocked Zakatable wealth and are supported by a global diaspora sending remittances through unofficial means. If these channels are integrated into national stratagem the opportunities for substantial and long-lasting change are unprecedented and partners such as UNHCR can truly optimize financial interventions for some of the most vulnerable people in a nation.

Therefore, today as we look forward to a post-corona world, it is urgent that we deeply consider what role Zakat needs to play to optimise its impact. We need to move beyond providing the poorest people with the most basic provision, we need to utilise Zakat to lift the poorest people. We need to take them on a journey of selfdevelopment and empowerment. We need to revive the tradition of investing in all Zakat categories and ensuring Zakat bodies have portfolios based on the divine mandate and not just the norms upon which they have operated since inception.

In this regard the case of UNHCR is singular and unique in the United Nations space, as it has put in place new and specific internal regulations and infrastructure for the distribution of Zakat funds (including in hard-to-reach areas), rather than using existing programmes as they were. This came after the receipt of 5 fatwas that govern UNHCR's approach to Zakat distribution, ensuring the respect of the scripture and the legitimacy from a compliance perspective. These edicts were received from internationally recognized scholars and institutions. The fatwas were summarized in a fatwa report (Furber, 2017), highlighting UNHCR's eligibility to distribute Zakat funds provided that it respects two primary conditions:

1. Zakat funds must be received by those mentioned in the Quran (9:60),

Following the juristic conditions, UNHCR only distributes Zakat to eligible beneficiaries that are most in need among refugees and internally displaced persons. These populations enter in at least five of the eight categories of Zakat:

a. Poor and Needy - Al Foqara' wa Al Masakeen (two categories): refugees and internally displaced persons supported tend to be poor or lacking assets or income. They have a limited ability to cover their basic everyday needs for themselves and their families. Some refugees and internally displaced persons might have had a good source of income, however, once forced to flee, most leave with no more than the clothes on their backs.

b. Debtors - Al Gharimun: refugees and internally displaced persons may be considered debtors, since, in many cases, they lose their homes, their belongings and personal possessions, which prompts them to incur debt to replace lost essentials. Even in the case where they were able to bring some money with them, years of displacement have exhausted their financial savings and forced them into debt to survive.

c. Wayfarers or Stranded Travelers Abna' Al Sabeel: a traveler, whilst they may be wealthy in his 
or her country of origin, is deemed to be stranded and consequently in need of financial assistance. Refugees, in most cases, can be categorized as stranded travelers who have fled their homes with limited resources and have undertaken a perilous journey to protect their families from conflict or persecution.

d. Those in bondage - Fil Riqab: while this is meant to help 'slaves' pay the debt that bonded them to their masters, which doesn't officially exist in its literal form anymore, this category can be projected on many refugees and internally displaced persons who are 'enslaved' by their uncertain situations or persecutors.

Therefore, focusing on refugees, IDPs and communities hosting them as well, has a wider impact on the spectrum of Zakat categories by benefiting several of them at once. Eligible beneficiaries are identified as per a vulnerability assessment framework, to guarantee the distribution of Zakat to the ones who deserve it who are in fact the most vulnerable and living under national extreme poverty lines.

\section{Zakat funds must not be used to cover expenses or wages.}

All United Nations organizations cover their salaries and other overhead costs by deducting a certain percentage on donations they receive. For UNHCR this amount is $6.5 \%$. This is standard for every single donation. However, the organization grants an exceptional waiver for Zakat donations, to ensure that $100 \%$ of Zakat received by UNHCR is distributed to beneficiaries, and thus respect the fatwa condition. That being said, any overhead costs associated with the distribution of Zakat funds are covered from other (non-Zakat) sources of funding for UNHCR. This is a bold approach and shows the respect given to managing Zakat funds by the agency, and should illustrate to Zakat agencies and partners the value of working with the agency.

In terms of distribution, Zakat funds are spent through UNHCR's cash assistance programmes. These programmes were in place before the distribution of Zakat, but it has been adapted to fit the specific considerations of Zakat mentioned above. When distribution in cash is not possible, Zakat is given in-kind. By ensuring their immediate needs, cash assistance helps prevent thousands of refugees who are restricted from working in host countries from facing severe hardships and enables them to address their needs according to their own priorities. It also helps in improving their social networks by repaying loans borrowed from family, neighbours, and landlords which therefore reduces household tensions. Additionally, it benefits the local economy by injecting cash that enables refugees to pay at local shops/ markets and for local services. Vulnerable families are often headed by women alone who often face cultural, legal and childcare obstacles when looking for work. Providing them with cash assistance helps prevent them from resorting to desperate survival strategies - such as pulling children out of school and child labour. In reality, cash assistance programmes. For example, an evaluation of the winter cash programme for Syrian refugees in Lebanon showed that cash assistance had a significant multiplier effect on the local economy: for each dollar spent, the programme generated about $\$ 2.13$ in gross domestic product for the Lebanese economy and had no significant impact on inflation (UNHCR, 2018). This shows how cash 
distribution contributes to the economic empowerment of the host community as well, in line with the spirit of Zakat as mentioned in the first part of this paper.

With this system in place, a pilot was launched end of 2016, which led to the UNHCR's Refugee Zakat Fund launch last year where UNHCR assisted over 1 million beneficiaries with Zakat, by distributing $\$ 43.165$ million. What is worth mentioning here is that:

- Over $90 \%$ of the funds were donated by Muslim foundations and charities from different countries (mainly in GCC);

- Foundation partners choose the destination of their Zakat funds based (Jordan, Lebanon, Bangladesh, Yemen, Mauritania, Iraq, etc.) which is a critical governance element in UNHCR's approach to Zakat.

Hence the benefit of strategic cooperation between Muslim charitable organizations and Zakat houses on one side, and multi-lateral organizations such as UNHCR on the other, in order to optimize the process and maximize the impact of the public well-being (al Maslaha al 'Amma). This partnership and cooperation model would allow Muslim organizations to benefit from the efficiency, transparency, best practices and large distribution networks while managing the funds according to their respective conditions and strategies. In addition, it is important to point out here that multi-lateral organizations usually have different kinds of humanitarian programmes. In the discussion about Zakat, this means that the distribution of Zakat can be given in different ways with different impact modalities, of course while respecting the scriptures. This also means that the impact of Zakatcompliant programmes will come in addition to the impact of other programmes. This is an important parameter to consider, as it promotes using Zakat in the context of a wide social empowerment scheme of the whole community, beyond considering Zakat as a poverty relief tool only.

Regarding Zakat for refugees in particular, Muslim organizations were eager to capitalize on UNHCR's compliance and effectiveness (in particular the fact that $100 \%$ of funds are distributed directly to beneficiaries as mentioned), as well as the wide outreach of UNHCR and its cash/ in-kind distribution networks, including hard-toreach areas where very few organizations can enter like in Yemen. Additionally, UNHCR was able to overcome challenges posed by financial regulations in some countries through partnerships with credible local entities and financial institutions, allowing the process of distribution to operate smoothly and in-line with local regulations. Other countries where Zakat is distributed include Jordan, Lebanon, Iraq, Mauritania and Bangladesh. As Zakat funds are spent to beneficiaries in the places and populations decided by the partner, this shows that Muslim organizations can keep control over Zakat management while getting the advantages of such a partnership model. This ends up being a model where multilateral organizations become key partners of Muslim organizations to implement their Zakat strategies effectively and widely.

From the multi-lateral organizations' perspective, this model opens a whole new source of resource mobilization, enabling them to impact more beneficiaries and diversify their partnerships, hence reducing funding gaps and risks. This is also an opportunity for multi-lateral organizations to learn more about 
Islamic philanthropy and discover new financing models (Zakat, Waqf, Sukuk, Sadaqah Jariyah...) that, when linked to the humanitarian expertise of these organizations, can lead to powerful tools towards realizing the SDGs. Promoting this partnership model will foster collaboration of international organizations with new partners among faith-based institutions and widen the scope of engagement with existing ones. This is a key component of the strategy of these organizations in their response to today's humanitarian challenges in the Muslim world and beyond.

\section{CONCLUSION}

We live in a world where 821 million people - more than 1 in 9 of the world population -do not get enough to eat (WFP, 2019), a world where wealth is increasing exponentially, along with poverty. Muslim countries are among the most affected by these humanitarian crises. There is, therefore, no doubt whatsoever on the key role Zakat needs to play in empowering communities and leading the needy towards a more dignified life. This will not be achieved if we do not deeply reflect on the spirit of Zakat and manage its funds accordingly. In view of current global regulations that require certain criteria for humanitarian and social assistance, this effort should be guided by authorised Islamic organizations. It is critical for a scripture-led societal strategy to be successful, the Islamic leadership is qualified to determine what constitutes an act of faith with the intention of maximizing the impact of Zakat through a partnership with entities, including international organisations, which can facilitate the delivery of programs for the best of vulnerable Muslim communities. This is a win-win situation whereby Zakat is delivered in the most effective and efficient way without violating the principles of Sharia and without Muslim organizations losing control over the process.

As the funding gap towards SDGs and humanitarian assistance is dramatic, and as a large part of this funding will be used in the Muslim world, there is a strategic alignment between Zakat principles and humanitarian goals. There can be a mutual partnership between both sides, with Islamic agencies leading the strategies related to the Zakat industry while capitalizing on the best practices of multi-lateral organizations in delivering Zakat funds with maximum impact for the beneficiaries and on the overall economy, thus providing new and more stable sources of funding to these organizations. This might require from the latter to adopt some of their existing processes and programmes to the specific requirements of Zakat or other forms of Islamic philanthropy, but this has been done at the infrastructure level and should be capitalized on and replicated for the better of the most vulnerable. At the heart of making this work though, is undoubtedly a need to revive a scripture led approach, and for Zakat agencies to ask existential questions of themselves, of who are they here to serve and how best can that service be executed for a better world.

\section{REFERENCES}

Furber, M. (2017, May). UNHCR zakat collection and distribution. Retrieved from https://unhcrzakatfatwa.com/wpcontent/uploads/2017/06/TR-1UNHCR-Zakat-Collection-AndDistribution-English.pdf. 
Rehman A. A. \& Pickup, F. (2018, September 7). Zakat for the SDGs. Retrieved from https://www.undp.org/content/undp/en/ home/blog/2018/zakat-for-thesdgs.html.

UN Deputy Secretary-General (2019, September 25). Citing \$2.5 Trillion Annual Financing Gap during SDG Business Forum Event, Deputy Secretary-General Says Poverty Falling Too Slowly. Retrieved from https://www.un.org/press/en/2019/dsgs m1340.doc.htm.

UNHCR (2018, June). Cash Assistance To Rohingya Refugees In Bangladesh. Retrieved from http://reporting.unhcr.org/sites/default/fi les/UNHCR\%20Cash\%20Assistance\%2 0to\%20Rohingya\%20Refugees\%20\%20June\%202018.pdf.

World Food Programme (2019, August 14). 2019-Hunger Map. Retrieved from https://www.wfp.org/publications/2019hunger-map.

Azim Kidwai

National Zakat Foundation Worldwide azim.kidwai@nzfworldwide.com

Mohamed El Mehdi Zidani

United Nations High Commissioner for Refugees (UNHCR) 